\title{
PATTERN RECOGNITION: EFFECTIVENESS OF TEACHING BOYS AGED 15 THE PRESS HEADSTAND AND HANDSTAND
}

\author{
Kyrylo Siedykh $^{1 \mathrm{ABCD}}$, Olha Ivashchenko ${ }^{1 \mathrm{ABCD}}$, Pavol Bartik ${ }^{2 \mathrm{ABD}}$ and Viktoria Veremeenko ${ }^{1 \mathrm{ABD}}$ \\ ${ }^{1}$ H. S. Skovoroda Kharkiv National Pedagogical University \\ ${ }^{2}$ Matej Bel University \\ Authors' Contribution: A - Study design; B - Data collection; C - Statistical analysis; D - Manuscript Preparation; E - Funds Collection
}

DOI: $10.17309 /$ jltm.2022.1.03

\begin{abstract}
Purpose. To determine the impact of exercise modes on the effectiveness of teaching boys aged 15 the press headstand and handstand.

Materials and methods. The study participants were 20 boys aged 15 . The children and their parents were fully informed about all the features of the study and gave their consent to participate in the experiment. To solve the tasks set, the following research methods were used: study and analysis of scientific and methodological literature; pedagogical observation, timing of training tasks; pedagogical experiment, methods of mathematical statistics, discriminant analysis.

Results. The assumption was made about a significant influence of the modes of alternating exercise repetitions and the rest interval on the effectiveness of teaching boys aged 15 the press headstand and handstand. The study found that statistically significant differences in the number of repetitions are observed in performing all training tasks. The boys aged 15 who use the second mode ( 6 sets 2 times each with a rest interval of $60 \mathrm{~s}$ ) need fewer repetitions to master series of motor tasks $1,3,4,5$, and 6 . The boys aged 15 who use the first mode ( 6 sets 1 time each with a rest interval of $60 \mathrm{~s}$ ) need fewer repetitions to master the second series of training tasks (exercises to master starting and ending positions).

Conclusions. The analysis of standardized, structure coefficients, and group centroids revealed that exercise modes significantly influence the process of teaching boys aged 15 the press headstand and handstand during physical education classes. The results of classification of the groups show that $100 \%$ of the original grouped cases were classified correctly. The study found that the mode of 6 sets 2 times each with a rest interval of $60 \mathrm{~s}$ is more effective than the mode of 6 sets 1 time with a rest interval of $60 \mathrm{~s}$ when teaching series of motor tasks 1, 3, 4, 5, and 6 .

Keywords: discriminant analysis, boys aged 15, acrobatic exercises, exercise mode, teaching.
\end{abstract}

\section{Introduction}

The importance of increasing motor activity of schoolchildren is highlighted by the findings of researchers (Prystynskyi, Babych, Zaytsev, Boychuk, \& Taymasov, 2020; Samsudin, Setiawan, Taufik, \& Solahuddin, 2021; Krutsevich, Marchenko, Trachuk, Panhelova, Napadij, \& Dovgal, 2021). It was found that the increase in motor activity is associated with the level of development of fundamental movements (Ré, Logan, Cattuzzo, Henrique, Tudela, \& Stodden, 2018; Peers, Issartel, Behan, O'Connor, \& Belton, 2020; Newell, 2020), the priority of motor skills development (Ivashchenko, Berezhna, \& Cieślicka, 2020; Ivashchenko \& Sirichenko, 2020; Khudolii, Golovnin, \& Bartík, 2020), as well as the development of teaching technologies (Khudolii, Iermakov, \& Bartik, 2020; Kapkan, Khudolii, \& Bartik, 2019; Shueva, Ivashchenko, \&

(c) Siedykh, K., Ivashchenko, O., Bartik, P., \& Veremeenko, V., 2022.
Jagiello, 2021). In the process of developing the skills of fundamental movements, it is also important to test the level of their development (Valentini, Zanella, \& Webster, 2017; Wagner, Kipling Webster, \& Ulrich, 2017; Webster, \& Ulrich, 2017).

One of the factors that influence the effectiveness of teaching is the mode of alternating repetitions and rest intervals (Marchenko \& Kovalenko, 2020; Marchenko, \& Taranenko, 2020; Marchenko, Jagiello, Iermakov, Ivashchenko, \& Khudolii, 2021). Ivashchenko and Karpunets (2001), Ivashchenko and Kapkan (2015), Browne, Flynn, O’Neill, Howatson, Bell, and Haskell-Ramsay (2017) point out a more significant impact of exercise modes on the effectiveness of performing complex coordination exercises. Thus, the study of the effectiveness of motor skills development is relevant.

The purpose of the study was to determine the impact of exercise modes on the effectiveness of teaching boys aged 15 the press headstand and handstand. 


\section{Materials and methods}

\section{Study participants}

The study participants were 20 boys aged 15 . The children and their parents were fully informed about all the features of the study and gave their consent to participate in the experiment.

\section{Organization of the study}

To solve the tasks set, the following research methods were used: study and analysis of scientific and methodological literature; pedagogical observation, timing of training tasks; pedagogical experiment, methods of mathematical statistics, discriminant analysis.

The pedagogical experiment examined the influence of 6 and 12 repetitions with a 60 -second rest interval during a physical education class on the number of repetitions of training tasks to the $100 \%$ level of proficiency. In the first group $(\mathrm{n}=10)$, the boys repeated the tasks 6 sets 1 time each with a rest interval of $60 \mathrm{~s}$, in the second group $(\mathrm{n}=10)-$ 6 sets 2 times each with a rest interval of $60 \mathrm{~s}$.

During teaching, the method of algorithmic instructions was used (Shlemin, 1973). The program of teaching the press headstand and handstand was developed based on the data of Shlemin (1973), Khudolii (2008) (Table 1).

Table 1. Program of teaching boys aged 15 the press headstand and handstand (Shlemin, 1973; Khudolii, 2008)

\begin{tabular}{lll}
\hline \multicolumn{1}{c}{$\begin{array}{c}\text { Informative frame } \\
\text { (what is performed) }\end{array}$} & \multicolumn{1}{c}{$\begin{array}{c}\text { Operational frame } \\
\text { (how it is performed) }\end{array}$} & $\begin{array}{c}\text { Control frame } \\
\text { (transition to training the next exercise) }\end{array}$ \\
\hline \multicolumn{2}{c}{ First series of training tasks - exercises to develop motor abilities } \\
\hline $\begin{array}{ll}\text { From standing position, with the back } \\
\text { against stall bars, proceed to arch hang }\end{array}$ & $\begin{array}{l}\text { Performed by jumping off both feet, hold } \\
\text { the position for 3-4 seconds }\end{array}$ & Reat 3-5 times \\
$\begin{array}{ll}\text { A push-up position. Bend arms and knees } \\
\text { (5 times in 5-6 seconds) }\end{array}$ & Performed with maximum amplitude & If the student performs the exercise for \\
\hline
\end{tabular}
(5 times in 5-6 seconds)

Second series of training tasks - exercises to master starting and ending positions

From squat, lean forward, put the head Hold the position for 3-4 seconds Repeat 3 times down on mat on the marking and evenly shift the body weight to the head and arms

The same, lifting the legs off the floor and Perform the exercise with assistance Repeat 3 times keeping them bent, straighten the back

Third series of training tasks - actions without which it is impossible to perform the target exercise

Lifting the legs off the floor and keeping them bent, straighten the back

Lifting the legs off the floor and keeping them bent, straighten the back

Arriving to headstand and handstand Repeat 3 times

should be done without any effort, by

simply straightening the legs

Push off with the feet and, helping with Repeat 3 times

hands, arrive to headstand. Straighten the legs

\begin{tabular}{|c|c|c|}
\hline $\begin{array}{l}\text { In kneeling position, bending and } \\
\text { straightening of the arms ( } 5 \text { times) }\end{array}$ & $\begin{array}{l}\text { Bend the arms simultaneously with } \\
\text { straightening the legs as quickly as } \\
\text { possible }\end{array}$ & $\begin{array}{l}\text { If the student performs the exercise for } \\
5-6 \text { seconds, proceed to the next exercise }\end{array}$ \\
\hline $\begin{array}{l}\text { Bending and straightening of the arms in } \\
\text { stoop standing position ( } 5 \text { times) }\end{array}$ & $\begin{array}{l}\text { Plant the hands on the floor a step's } \\
\text { length away from the toes }\end{array}$ & $\begin{array}{l}\text { If the student performs the exercise for } \\
5-6 \text { seconds, proceed to the next exercise }\end{array}$ \\
\hline $\begin{array}{l}\text { From normal standing position, lean } \\
\text { forward, touch the floor with the hands } \\
\text { and, moving the hands forward on the floor, } \\
\text { adopt a push-up position, return to starting } \\
\text { position in the same way }\end{array}$ & $\begin{array}{l}\text { Do not bend knees when performing the } \\
\text { exercise }\end{array}$ & Perform the exercise for 6 seconds \\
\hline
\end{tabular}
position in the same way

Fifth series of training tasks - preliminary exercises

From squat, lean forward, put the head down on mat and evenly shift the body weight to the head and arms for 3-4 seconds

From squat, lean forward, put the head down on mat on the marking and evenly shift the body weight to the head and arms

A headstand with the back and legs against the stall bars, without assistance

Straightening the back, hold balance If the student performs the exercise 3 times,
with bent legs proceed to the next exercise

Straighten the legs, hold balance without Correct performance of the series on bending the legs for 3-4 seconds 3 attempts

Focus on the exercise technique Correct performance of the series on 3 attempts

Sixth series of training tasks - the entire exercise

A headstand with the back and legs against the stall bars, with assistance

A headstand with the back and legs against the stall bars, without assistance

A headstand without assistance
Hold the position for 5-6 seconds

Hold the position for 5-6 seconds

Hold the position for 5-6 seconds
Correct performance of the series on 3 attempts

Correct performance of the series on 3 attempts 
ISSN 2708-7581 (Online). ISSN-L 2708-7573. Journal of Learning Theory and Methodology. 2022. Volume 3, Number 1

Table 2. Group Statistics. Boys Aged 15

\begin{tabular}{|c|c|c|c|c|c|c|c|c|c|c|}
\hline \multirow[t]{2}{*}{ Series of tasks } & \multicolumn{2}{|c|}{$\begin{array}{c}6 \text { repetitions, rest interval of } \\
60 \mathrm{~s}\end{array}$} & \multicolumn{2}{|c|}{$\begin{array}{c}12 \text { repetitions, rest interval } \\
\text { of } 60 \mathrm{~s} \\
\end{array}$} & \multirow[t]{2}{*}{$\Delta \mathbf{x}$} & \multirow{2}{*}{$\begin{array}{l}\text { Wilks' } \\
\text { Lambda }\end{array}$} & \multirow[t]{2}{*}{ F } & \multirow[t]{2}{*}{ df1 } & \multirow[t]{2}{*}{ df2 } & \multirow[t]{2}{*}{ Sig. } \\
\hline & Mean & Std. Deviation & Mean & $\overline{\text { Std. Deviation }}$ & & & & & & \\
\hline 1 & 8.2 & 1.61 & 4.7 & 1.33 & 3.5 & .393 & 27.771 & 1 & 18 & .000 \\
\hline 2 & 8.6 & 1.64 & 6.6 & 1.57 & 2 & .701 & 7.692 & 1 & 18 & .013 \\
\hline 3 & 11.2 & 1.47 & 14.2 & 2.09 & -3 & .568 & 13.682 & 1 & 18 & .002 \\
\hline 4 & 16.0 & 1.49 & 12.3 & 1.25 & 3.7 & .333 & 36.132 & 1 & 18 & .000 \\
\hline 5 & 8.9 & 1.52 & 6.7 & 1.33 & 2.2 & .605 & 11.773 & 1 & 18 & .003 \\
\hline 6 & 7.9 & 1.28 & 6.4 & 1.34 & 1.5 & .736 & 6.470 & 1 & 18 & .020 \\
\hline
\end{tabular}

The next exercise started on condition of correct performance of the previous exercise on three consecutive attempts. The number of repetitions required for correct performance on three consecutive attempts was recorded. The level of proficiency in the exercises was determined by the alternative method: "performed" or "failed". A technically correct performance of the exercise gave the students " 1 " point; a failure to perform the exercise gave them " 0 " entered in the protocol.

\section{Statistical analysis}

The study materials were processed using the IBM SPSS 20 statistical analysis program. Discriminant analysis was conducted. For each canonical discriminant function, the study calculated the following: eigenvalue, variance percentage, canonical correlation, Wilks' lambda, Chi-square. For each step: prior probabilities, Fisher's function coefficients, unstandardized function coefficients, Wilks' lambda for each canonical function.

The study protocol was approved by the Ethical Committee of the University. In addition, the children and their parents or legal guardians were fully informed about all the features of the study, and a signed informed consent document was obtained from all the parents.

\section{Results}

The analysis of averages shows that statistically significant differences in the number of repetitions are observed in performing all training tasks. The boys aged 15 who use the second mode ( 6 sets 2 times each with a rest interval of $60 \mathrm{~s}$ ) need fewer repetitions to master series of training tasks 1,3 , 4,5 , and 6 . The boys aged 15 who use the first mode ( 6 sets 1 time each with a rest interval of $60 \mathrm{~s}$ ) need fewer repetitions to master the second series of training tasks (exercises to master starting and ending positions) (Table 2).

To determine the impact of different modes of exercises on the level of proficiency, discriminant analysis was conducted (Tables 3-10). A necessary condition for discriminant analysis is the homogeneity of variances and covariances of data. The Box's $M$ test confirms the assumption about the homogeneity of variances and covariances (Table 3 ).

The first canonical function explains $100 \%$ of the results variation, which indicates its high informativity $(r=0.935)$ (see Table 4). The analysis of the canonical function shows its statistical significance $\left(\lambda_{1}=0.125 ; p_{1}=0.001\right)$. The first function has a high discriminative ability and value in interpretation of the general population (Table 5).
Table 3. Box's M Test For Testing Equal Population

Covariance Matrices (DA)

\begin{tabular}{rlr}
\hline & Box's $\mathbf{M}$ & $\mathbf{3 3 . 2 3 6}$ \\
\hline \multirow{4}{*}{ F } & Approx. & .996 \\
& df1 & 21 \\
& df2 & 1191.671 \\
& Sig. & .465 \\
\hline
\end{tabular}

Table 4. Eigenvalues for Developing Discriminant Model (Canonical Correlation). Boys Aged 15

\begin{tabular}{ccccc}
\hline Function & Eigenvalue & $\begin{array}{c}\% \text { of } \\
\text { Variance }\end{array}$ & $\begin{array}{c}\text { Cumulative } \\
\%\end{array}$ & $\begin{array}{c}\text { Canonical } \\
\text { Correlation }\end{array}$ \\
\hline 1 & $6.988^{\mathrm{a}}$ & 100.0 & 100.0 & .935 \\
\hline
\end{tabular}

Table 5. Outcomes of Calculated Wilks' Lambda of Discriminant Function. Boys Aged 15

\begin{tabular}{ccccc}
\hline Test of Function(s) & Wilks' Lambda & Chi-square & df & Sig. \\
\hline 1 & .125 & 31.169 & 6 & .000 \\
\hline
\end{tabular}

The standardized canonical discriminant function coefficients make it possible to determine the ratio of the contribution of variables to the function result. The results of the first (exercises to develop motor abilities) and the fourth (teaching the ability to assess movements in space, by time and muscular effort) series of training tasks make the largest contribution to the first canonical function. The above indicates that in the classification of exercise modes for boys aged 15 , the exercises of the first and fourth series of training tasks are a priority (Table 6).

The structure canonical discriminant function coefficients are the coefficients of correlation between the variables and the function. Thus, the function is most closely connected with the number of repetitions of exercises of the fourth and first series of training tasks $\left(\mathrm{r}_{4}=0.536 ; \mathrm{r}_{1}=0.470\right)$ (Table 7).

Table 6. Standardized Canonical Discriminant Function Coefficients. Boys Aged 15

\begin{tabular}{cc}
\hline Series of tasks & Function \\
\cline { 2 - 2 } & $\mathbf{1}$ \\
\hline Series 1 & .695 \\
Series 2 & -.541 \\
Series 3 & -.536 \\
Series 4 & .858 \\
Series 5 & .472 \\
Series 6 & .116 \\
\hline
\end{tabular}


Table 7. Structure Matrix. Boys Aged 15

\begin{tabular}{cc}
\hline \multirow{2}{*}{ Series of tasks } & Function \\
\cline { 2 - 2 } & $\mathbf{1}$ \\
\hline Series 4 & .536 \\
Series 1 & .470 \\
Series 3 & -.330 \\
Series 5 & .306 \\
Series 2 & .247 \\
Series 6 & .227 \\
\hline
\end{tabular}

Table 8. Canonical Discriminant Function Coefficients (Unstandardized coefficients)

\begin{tabular}{cc}
\hline Series of tasks & Function \\
\cline { 2 - 2 } & $\mathbf{1}$ \\
\hline Series 1 & .468 \\
Series 2 & -.336 \\
Series 3 & -.296 \\
Series 4 & .623 \\
Series 5 & .329 \\
Series 6 & .088 \\
(Constant) & -8.725 \\
\hline
\end{tabular}

Table 9. Functions at Group Centroids. Boys Aged 15

\begin{tabular}{lc}
\hline \multicolumn{1}{c}{ Exercise Mode } & Function \\
\cline { 2 - 2 } & $\mathbf{1}$ \\
\hline $1-6$ repetitions, rest interval of $60 \mathrm{~s}$ & 2.508 \\
$2-12$ repetitions, rest interval of $60 \mathrm{~s}$ & -2.508 \\
\hline
\end{tabular}

The coordinates of centroids for two groups make it possible to interpret the canonical function in relation to the role in classification. At the positive pole is a centroid for the exercise mode of 6 repetitions $\left(M_{6}=2.508\right)$, at the negative $-\mathrm{a}$ centroid for the exercise mode of 12 repetitions $\left(M_{12}=-2.508\right)$ (see Table 9, Fig. 1, 2). This indicates a significant difference in the impact of exercise repetition modes on the number of repetitions required for motor skills development in boys aged 15 during physical education classes. The results of classification of the groups show that $100.0 \%$ of the original grouped cases were classified correctly (Table 10). Based on the discriminant function coefficients and centroids, it is possible to calculate
Canonical Discriminant Function 1

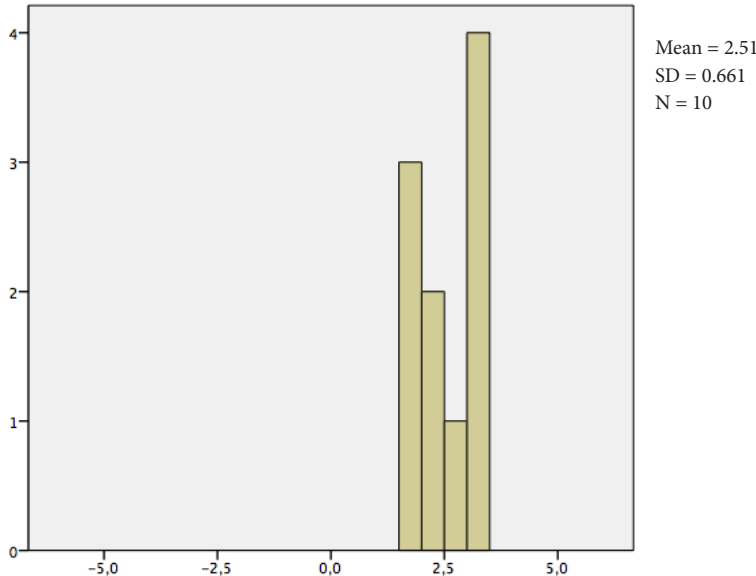

Fig. 1. Graphic representation of classification results: 6 repetitions, rest interval of $60 \mathrm{~s}$

Canonical Discriminant Function 1

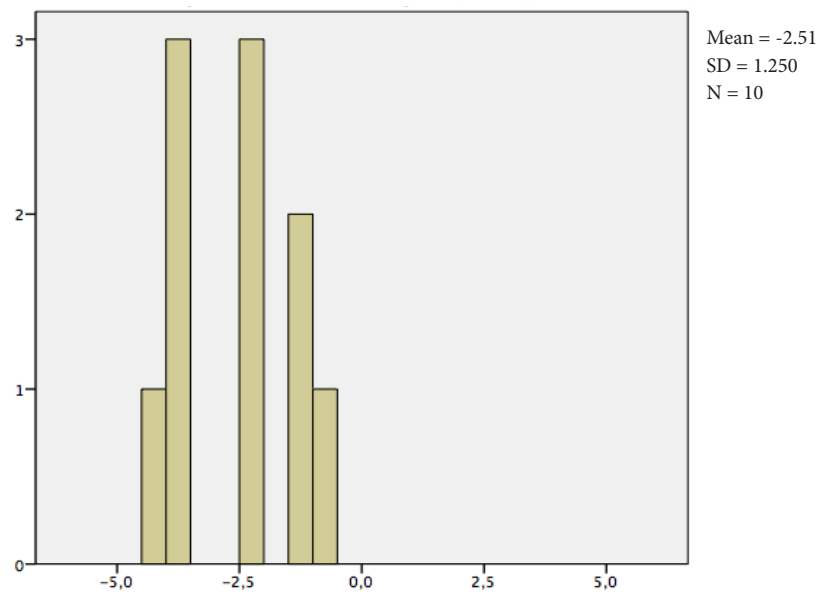

Fig. 2. Graphic representation of classification results: 12 repetitions, rest interval of $60 \mathrm{~s}$

the number of repetitions for mastering the motor skill (Table 8 ). The value of the centroid for the exercise mode of 12 repetitions is approximate for calculation $\left(\mathrm{M}_{12}=-2.508\right)$.

Table 10. Classification Results ${ }^{\mathrm{a}, \mathrm{c}}$

\begin{tabular}{|c|c|c|c|c|c|}
\hline & & \multirow{2}{*}{ Exercise Mode } & \multicolumn{2}{|c|}{ Predicted Group Membership } & \multirow{2}{*}{ Total } \\
\hline & & & 1 & 2 & \\
\hline \multirow{4}{*}{ Original } & \multirow{2}{*}{ Count } & $1-6$ repetitions, rest interval of $60 \mathrm{~s}$ & 10 & 0 & 10 \\
\hline & & $2-12$ repetitions, rest interval of $60 \mathrm{~s}$ & 0 & 10 & 10 \\
\hline & \multirow{2}{*}{$\%$} & $1-6$ repetitions, rest interval of $60 \mathrm{~s}$ & 100.0 & .0 & 100.0 \\
\hline & & $2-12$ repetitions, rest interval of $60 \mathrm{~s}$ & .0 & 100.0 & 100.0 \\
\hline \multirow{4}{*}{ Cross-validated ${ }^{\mathrm{b}}$} & \multirow{2}{*}{ Count } & $1-6$ repetitions, rest interval of $60 \mathrm{~s}$ & 10 & 0 & 10 \\
\hline & & $2-12$ repetitions, rest interval of $60 \mathrm{~s}$ & 1 & 9 & 10 \\
\hline & \multirow{2}{*}{$\%$} & $1-6$ repetitions, rest interval of $60 \mathrm{~s}$ & 100.0 & .0 & 100.0 \\
\hline & & $2-12$ repetitions, rest interval of $60 \mathrm{~s}$ & 10.0 & 90.0 & 100.0 \\
\hline
\end{tabular}

a. $100.0 \%$ of original grouped cases correctly classified.

b. Cross validation is done only for those cases in the analysis. In cross validation, each case is classified by the functions derived from all cases other than that case.

c. $100.0 \%$ of cross-validated grouped cases correctly classified. 


\section{Discussion}

The assumption was made about a significant influence of the modes of alternating exercise repetitions and the rest interval on the effectiveness of teaching boys aged 15 the press headstand and handstand. The study found that statistically significant differences in the number of repetitions are observed in performing all training tasks. The boys aged 15 who use the second mode ( 6 sets 2 times each with a rest interval of $60 \mathrm{~s}$ ) need fewer repetitions to master series of motor tasks $1,3,4,5$, and 6 . The boys aged 15 who use the first mode ( 6 sets 1 time each with a rest interval of $60 \mathrm{~s}$ ) need fewer repetitions to master the second series of training tasks (exercises to master starting and ending positions) (Table 2).

The obtained data complement the knowledge about the regularities of motor skills development in children and adolescents (Ré, Logan, Cattuzzo, Henrique, Tudela, \& Stodden, 2018; Peers, Issartel, Behan, O’Connor, \& Belton, 2020; Newell, 2020).

The analysis of standardized and structure discriminant function coefficients shows that in the process of teaching the press headstand and handstand, previous strength training (first series of tasks) and the ability to control movements (fourth series) are a priority. This confirms the information on the impact of exercise modes with a complex coordination structure (Browne et al., 2017).

The results of the analysis of the teaching process confirm the effectiveness of the discriminant function for determining the regularities of motor skills development and complement the knowledge about its use in physical education and sports (Broadhead \& Church, 1982; Baudry, Sforza, Leroy, Lovecchio, Gautier, \& Thouvarecq, 2009; Kermarrec, \& Michot, 2007).

To plan the modes of exercises on the basis of discriminant function coefficients and centroids, it is possible to calculate the number of repetitions for mastering the motor skill. The calculation is performed using the following equation:

$\mathrm{Y}=-8.725+0.468 \mathrm{X}_{1}-0.336 \mathrm{X}_{2}-0.296 \mathrm{X}_{3}+0.623 \mathrm{X}_{4}+0.329 \mathrm{X}_{5}+$ $+0.088 \mathrm{X}_{6}$, where $\mathrm{Y}$ is the function result, $\mathrm{X}_{1}-\mathrm{X}_{6}$ are the number of repetitions of series of training tasks 1-6.

The value of the centroid for the exercise mode of 12 repetitions is approximate for calculation $\left(M_{12}=-2.508\right)$.

\section{Conclusions}

The analysis of standardized, structure coefficients, and group centroids revealed that exercise modes significantly influence the process of teaching boys aged 15 the press headstand and handstand during physical education classes. The results of classification of the groups show that $100 \%$ of the original grouped cases were classified correctly.

The study found that the mode of 6 sets 2 times each with a rest interval of $60 \mathrm{~s}$ is more effective than the mode of 6 sets 1 time with a rest interval of $60 \mathrm{~s}$ when teaching series of motor tasks $1,3,4,5$, and 6 .

\section{Acknowledgment}

The study was carried out according to the research plan of the Department of Theory and Methodology of Physical
Education of H. S. Skovoroda Kharkiv National Pedagogical University within the topic "Theoretical and methodological foundations of modeling the learning process and motor abilities development in children and adolescents" (20132022) (state registration number 0112U002008).

\section{Conflict of interest}

The authors declare that there is no conflict of interest.

\section{References}

Prystynskyi, V., Babych, V., Zaytsev, V., Boychuk, Y., \& Taymasov, Y. (2020). Impact of Updated Curriculum Content on 6th-7th Graders' Motivation in Physical Education. Teoriâ ta Metodika Fizičnogo Vihovannâ, 20(2), 117-123. https://doi.org/10.17309/tmfv.2020.2.08

Samsudin, S., Setiawan, I., Taufik, M., \& Solahuddin, S. (2021). Volleyball Fundamental Movement Learning Model in Primary School. Teoriâ ta Metodika Fizičnogo Vihovannâ, 21(3), 194-199. https://doi.org/10.17309/tmfv.2021.3.02

Krutsevich, T., Marchenko, O., Trachuk, S., Panhelova, N., Napadij, A., \& Dovgal, V. (2021). The Configuration of Educational Factors in the Family in Terms of their Impact on the Formation of Interest in Sports in Middle School Children. Teoriâ ta Metodika Fizičnogo Vihovannâ, 21(2), 101-106. https://doi.org/10.17309/tmfv.2021.2.01

Ré, A. H. N., Logan, S. W., Cattuzzo, M. T., Henrique, R. S., Tudela, M. C., \& Stodden, D. F. (2018). Comparison of motor competence levels on two assessments across childhood. Journal of Sports Sciences, 36(1), 1-6. https://doi.org/10.1080/02640414.2016.1276294

Peers, C., Issartel, J., Behan, S., O'Connor, N., \& Belton, S. (2020). Movement competence: Association with physical self-efficacy and physical activity. Human Movement Science, 70. https://doi.org/10.1016/j.humov.2020.102582

Newell, K. M. (2020). What are Fundamental Motor Skills and What is Fundamental about Them? Journal of Motor Learning and Development, 8(2), 280-314. https://doi.org/10.1123/JMLD.2020-0013

Ivashchenko, O., Berezhna, H., \& Cieślicka, M. (2020). Motor Skills in the Structure of Physical Fitness of 7-Year-Old Boys. Journal of Learning Theory and Methodology, 1(1), 14-19. https://doi.org/10.17309/jltm.2020.1.02

Ivashchenko, O., \& Sirichenko, D. (2020). Structure of Motor Fitness of 7-Year-Old Girls. Journal of Learning Theory and Methodology, 1(1), 20-25. https://doi.org/10.17309/jltm.2020.1.03

Khudolii, O., Golovnin, V., \& Bartík, P. (2020). Peculiarities of Motor Fitness Structure of 9-Year-Old Girls. Journal of Learning Theory and Methodology, 1(2), 53-57. https://doi.org/10.17309/jltm.2020.2.01

Khudolii, O., Iermakov, S., \& Bartik, P. (2020). Didactics: Methodological Basis of Motor Learning in Children and Adolescents. Journal of Learning Theory and Methodology, 1(1), 5-13. https://doi.org/10.17309/jltm.2020.1.01

Kapkan, O., Khudolii, O., \& Bartik, P. (2019). Pattern Recognition: Motor Skills Development in Girls Aged 15. Teoriâ ta Metodika Fizičnogo Vihovannâ, 19(1), 44-52. https://doi.org/10.17309/tmfv.2019.1.06 
Shueva, A., Ivashchenko, O., \& Jagiello, W. (2021). Motor Skills Development: Peculiarities of Programmed Teaching of Acrobatic Exercises to Girls Aged 15. Teoriâ ta Metodika Fizičnogo Vihovannâ, 21(4), 350-356. https://doi.org/10.17309/tmfv.2021.4.10

Valentini, N. C., Zanella, L. W., \& Webster, E. K. (2017). Test of Gross Motor Development- third edition: Establishing content and construct validity for Brazilian children. Journal of Motor Learning and Development, 5(1), 15-28. https://doi.org/10.1123/jmld.2016-0002

Wagner, M. O., Kipling Webster, E., \& Ulrich, D. A. (2017). Psychometric properties of the Test of Gross Motor Development, third edition (German Translation): Results of a pilot study. Journal of Motor Learning and Development, 5(1), 29-44. https://doi.org/10.1123/jmld.2016-0006

Webster, E. K., \& Ulrich, D. A. (2017). Evaluation of the psychometric properties of the Test of Gross Motor Development-third edition. Journal of Motor Learning and Development, 5(1), 45-58. https://doi.org/10.1123/jmld.2016-0003

Marchenko, S., \& Kovalenko, K. (2020). Optimization of Teaching Boys Aged 10 Mae-Geri (Front Kick) Technique in Kyokushin Karate. Journal of Learning Theory and Methodology, 1(1), 33-39.

https://doi.org/10.17309/jltm.2020.1.05

Marchenko, S., \& Taranenko, O. (2020). Managing the Effectiveness of Teaching Boys Aged 10 MawashiGeri (Roundhouse Kick) Technique in Kyokushin Karate. Teoriâ ta Metodika Fizičnogo Vihovannâ, 20(4), 262-268. https://doi.org/10.17309/tmfv.2020.4.10

Marchenko, S., Jagiello, W., Iermakov, S., Ivashchenko, O., \& Khudolii, O. (2021). Pattern recognition: modes of teaching boys aged 10 mae-geri (front kick) technique in kyokushin karate. ARCH BUDO, 17, 253-261.
Ivashchenko, O. V., \& Karpunets, T. V. (2001). Normatyvni pokaznyky trenuvalnykh navantazhen na pochatkovomu etapi pidhotovky yunykh himnastok 6-8 rokiv.Teoriâ ta Metodika Fizičnogo Vihovannâ, (3), 19-24. Retrieved from https://tmfv.com.ua/journal/article/view/23

Ivashchenko, O. V., \& Kapkan, O. O. (2015). Simulation of process of 14-15 years old girls' training of light athletic and gymnastic exercises. Pedagogics, psychology, medicalbiological problems of physical training and sports, 19(8), 32-39. https://doi.org/10.15561/18189172.2015.0805

Browne, S. E., Flynn, M. J., O’Neill, B. V., Howatson, G., Bell, P. G., \& Haskell-Ramsay, C. F. (2017). Effects of acute high-intensity exercise on cognitive performance in trained individuals: A systematic review. Progress in Brain Research, 234, 161-187. https://doi.org/10.1016/bs.pbr.2017.06.003

Shlemin, A.M. (1973). Iunyi gimnast. M.: Fizkultura i sport, 376.

Khudolii, O.M. (2008). Osnovy metodyky vykladannia himnastyky: Navch. posibnyk. U 2-kh tomakh. 4-e vyd., vypr. i dop. Kharkiv: “OVS”, T. 1, 408.

Broadhead, G. D., \& Church, G. E. (1982). Discriminant analysis of gross and fine motor proficiency data. Perceptual and motor skills, 55(2), 547-552. https://doi.org/10.2466/pms.1982.55.2.547

Baudry, L., Sforza, C., Leroy, D., Lovecchio, N., Gautier, G., \& Thouvarecq, R. (2009). Amplitude variables of circle on the pedagogic pommel horse in gymnastics. Journal of Strength and Conditioning Research, 23(3), 705-711. https://doi.org/10.1519/JSC.0b013e3181a00be8

Kermarrec, G., \& Michot, T. (2007). Development and validation of a scale to measure learning strategies by adolescents in physical education and sports. Canadian Journal of Behavioural Science, 39(3), 235-245. https://doi.org/10.1037/cjbs2007018

\title{
РОЗПІЗНАННЯ ОБРАЗІВ: ЕФЕКТИВНІСТЬ ПРОЦЕСУ НАВЧАННЯ СТІЙКИ СИЛОЮ НА ГОЛОВІ І РУКАХ ХЛОПЦІВ 15 РОКІВ
}

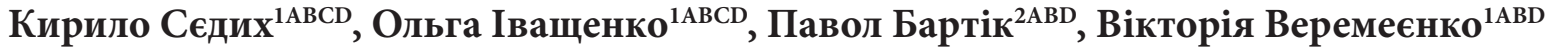 \\ ${ }^{1}$ Харківський національний педагогічний університет імені Г.С. Сковороди \\ ${ }^{2}$ Університет Матея Беля
}

Авторський вклад: А - дизайн дослідження; В - збір даних; C - статаналіз; D - підготовка рукопису; Е - збір коштів

Реферат. Статья: 7 с., 9 табл., 2 рис., 26 джерел.

\begin{abstract}
Мета дослідження - визначити вплив режимів виконання вправ на ефективність процесу навчання стійки силою на голові і руках хлопців 15 років.

Матеріали і методи. У дослідженні прийняли участь 20 хлопців 15 років. Діти та їхні батьки були інформовані про всі особливості дослідження і дали згоду на участь в експерименті. Для вирішення поставлених завдань були використані методи дослідження: вивчення та аналіз науково-методичної літератури; педагогічне спостереження, хронометраж навчальних завдань; педагогічний експеримент, методи математичної статистики, дискримінантний аналіз.
\end{abstract}

Результати. Приймається припущення про суттєвий вплив режимів чергування повторень вправ та інтервалу відпочинку на ефективність навчання стійки силою на голові і руках хлопців 15 років. Встановлено, що статистично значущі розбіжності у кількості повторень спостерігаються у виконанні всіх навчальних завдань. Хлопці 15 років, які використовують другий режим (6 підходів по 2 рази з інтервалом відпочинку 60 с), витрачають менше повторень на оволодіння 1, 3, 4, 5 та 6 серії рухових завдань. Хлопці 15 років, які використовують перший режим (6 підходів по 1 разу з інтервалом відпочинку 60 с) витрачають менше повторень 
на оволодіння другої серії навчальних завдань (вправи на оволодіння вихідних і кінцевих положень).

Висновки. На основі аналізу нормованих, структурних коефіцієнтів та центроїдів груп визначено, що режими виконання вправ мають суттєвий вплив на процес навчання стійки силою на голові і руках хлопців 15 років на уроках фізичної культури. Результати класифікації груп показу- ють, що 100 \% вихідних згрупованих спостережень класифіковано вірно. Встановлено що режим 6 підходів по 2 рази з інтервалом відпочинку 60 с має більшу ефективність ніж режим 6 підходів по 1 разу з інтервалом відпочинку 60 с у процесі навчання 1, 3, 4, 5 та 6 серії рухових завдань.

Ключові слова: дискримінантний аналіз, хлопці 15 років, акробатичні вправи, режим виконання вправ, навчання.

\section{Information about the authors:}

Siedykh Kyrylo: kirillsedyh59@gmail.com; https://orcid.org/0000-0002-8388-562X; Department of Theory and Methodology of Physical Education, H. S. Skovoroda Kharkiv National Pedagogical University, Alchevskikh St, 29, Kharkiv, 61002, Ukraine.

Ivashchenko Olha: ivashchenko@hnpu.edu.ua; https://orcid.org/0000-0002-2708-5636; Department of Theory and Methodology of Physical Education, H. S. Skovoroda Kharkiv National Pedagogical University, Alchevskykh St., 29, 61002, Kharkiv, Ukraine.

Bartik Pavol: pavol.bartik@umb.sk; https://orcid.org/0000-0002-2087-7876; Department of Physical Education and Sports, Matej Bel University, Tajovskeho 40, 97401 Banska Bystrica, Slovakia.

Veremeenko Viktoria: viktoriaveremeenko91@gmail.com; https://orcid.org/0000-0002-9826-9678, Department of Theory and Methodology of Physical Education, H. S. Skovoroda Kharkiv National Pedagogical University, Alchevskikh St, 29, Kharkiv, 61002, Ukraine.

Cite this article as: Siedykh, K., Ivashchenko, O., Bartik, P., \& Veremeenko, V. (2022). Pattern Recognition: Effectiveness of Teaching Boys Aged 15 the Press Headstand and Handstand. Journal of Learning Theory and Methodology, 3(1), 18-24. https://doi.org/10.17309/jltm.2022.1.03

Received: 25.10.2021. Accepted: 05.02.2022. Published: 28.02.2022

This work is licensed under a Creative Commons Attribution 4.0 International License (http://creativecommons.org/licenses/by/4.0). 